\title{
Review \\ A Review on Atrial Fibrillation (Computer Simulation and Clinical Perspectives)
}

\author{
Muhammad Adib Uz Zaman *(1) and Dongping Du (1) \\ Department of Industrial, Manufacturing and Systems Engineering, Texas Tech University, \\ Lubbock, TX 79409, USA; dongping.du@ttu.edu \\ * Correspondence: a_u_z_ipe@yahoo.com; Tel.: +1-815-593-5933
}

check for updates

Citation: Zaman, M.A.U.; Du, D. A Review on Atrial Fibrillation (Computer Simulation and Clinical Perspectives). Hearts 2022, 3, 20-37. https://doi.org/10.3390/

hearts3010005

Academic Editor: Matthias Thielmann

Received: 17 November 2021 Accepted: 11 February 2022 Published: 14 February 2022

Publisher's Note: MDPI stays neutral with regard to jurisdictional claims in published maps and institutional affiliations.

Copyright: (C) 2022 by the authors. Licensee MDPI, Basel, Switzerland. This article is an open access article distributed under the terms and conditions of the Creative Commons Attribution (CC BY) license (https:// creativecommons.org/licenses/by/ $4.0 /)$.

\begin{abstract}
Atrial fibrillation (AF), a heart condition, has been a well-researched topic for the past few decades. This multidisciplinary field of study deals with signal processing, finite element analysis, mathematical modeling, optimization, and clinical procedure. This article is focused on a comprehensive review of journal articles published in the field of AF. Topics from the ageold fundamental concepts to specialized modern techniques involved in today's AF research are discussed. It was found that a lot of research articles have already been published in modeling and simulation of AF. In comparison to that, the diagnosis and post-operative procedures for AF patients have not yet been totally understood or explored by the researchers. The simulation and modeling of AF have been investigated by many researchers in this field. Cellular model, tissue model, and geometric model among others have been used to simulate AF. Due to a very complex nature, the causes of AF have not been fully perceived to date, but the simulated results are validated with real-life patient data. Many algorithms have been proposed to detect the source of AF in human atria. There are many ablation strategies for AF patients, but the search for more efficient ablation strategies is still going on. AF management for patients with different stages of AF has been discussed in the literature as well but is somehow limited mostly to the patients with persistent AF. The authors hope that this study helps to find existing research gaps in the analysis and the diagnosis of AF.
\end{abstract}

Keywords: atrial fibrillation; review; ablation; simulation; modeling; cardiac rhythm

\section{Introduction and Background}

AF is one of the most common types of cardiac arrhythmia and affects more than 2 million people in the United States alone [1]. In a healthy human heart, the cardiac rhythm is regular and controlled by the sinoatrial node. While a regular heart beat is between 60 and 100 per min, an AF patient's heart beat might rise to more than 150 beats per minute. AF is mainly caused by irregular and chaotic electrical signals (other than the one from the sinoatrial node in the right atrium) generated inside the left atrium (note that much evidence also suggests that AF could be originated from the right atrium). Therefore, the atria cannot beat strongly and regularly. Instead, they quiver, and the blood is not circulated through the ventricles well enough. Though there could be several other reasons (such as high blood pressure, heart attacks, congenital heart disease, viral infections, and abnormal trigger) that cause AF in real life, not all of them are well understood yet. One of the many causes of AF is attributed to atrial remodeling [2] which can be electrical, structural, or neural [3-5]. Atrial remodeling is defined as any change in atrial structure or function that can lead to atrial arrhythmia. It can be caused by underlying heart conditions, systematic processes, aging, and even AF itself. There are different stages of AF such as paroxysmal, persistent, permanent, etc. [6]. All of these are diagnosed differently depending upon the severeness and feasibility. It has been many years since AF mechanisms have been researched clinically, but the AF initiation and maintenance still remain mysterious. This paper aims to review some of the latest and most important advancements in simulation 
and computer experiments of AF research and present a brief overview of the ongoing progress in these fields.

Computer simulation has been widely used for AF research. The initiation dates back to 1952 [7] when the cellular membrane currents were explored that eventually lead to the electro-physiological model of AF [8,9]. This model considers the cell membrane as a capacitor that is connected in parallel with many variable resistances (also batteries), representing both of the ionic channels and driving forces. After a few more years, a computer model of AF was proposed [10]. Since then, many other researchers [8,11] have been working to develop mathematical simulation models to explain AF based on its electro-physical characteristics. Some of them have quite successfully validated their models corresponding to real-life data [11]. Computer modeling of AF is mostly based on the cellular automata and detailed cell electro-physiology models. In recent years, multi-scale modeling [11] of electrical propagation became popular. Cellular modeling is mostly based on two approaches. One is a reduced two-variable simplified (asymptotic) model [12], and another is the detailed electro-physiological model [8]. Apart from these, geometric and image-based atrial modeling has been explored as well [1] by many using those two cellular models, simple 2D geometric shapes, and cardiovascular magnetic resonance (CMR)-based organ-level models with complex 3D shapes. Therefore, there are different established modeling approaches available for AF simulation, and most of them found success as observed in the literature. Still, the improvement in AF modeling has been noticeable during the last couple of years.

AF has been modeled in different ways-electrical, structural, etc. The electrical, structural, and their combined modeling have been compared [13] in the literature. The correlation between decreasing wavelength and reentry of AF (flutter) episodes has been discussed as well. There appears to be no significant difference in the average re-entry time between the two (electrical and structural) modeling approaches, although their dynamics are completely different. This study was inspired by the investigation of critical wavelength $(9-11 \mathrm{~cm})$ for the re-entry of wavelets in a biophysical model [14]. Stochastic onset and termination of AF in a cellular automata model are described in [15] the literature. Tissue remodeling in fibrotic lesions has also been investigated [16]. In order to aid in the diagnosis, AF modeling and simulation [17-21] have been some well-researched topics in the literature.

One of the methods found in the literature for AF treatment is catheter ablation-one variation of which basically isolates the pulmonary veins (PV) in the LA and thus removes the trigger (e.g., supraventricular extrasystoles/fast electrical signals) of AF. However, in most real-life cases, the patients are prescribed anti-arrhythmia drugs (AAD) for rhythm control. However, a recent study [22] on early rhythm control therapy discussed EASTAFNET 4 trials where catheter ablation was chosen as an initial therapy for around $8 \%$ of the patients. Many methods have been proposed to determine the area to be ablated in a clinical trial. There are many complications associated with ablation that may hamper the recovery of AF patients [23]. In the literature, the outcomes of ablation seem to be suboptimal, and thus, a search of ablation of AF drivers was initiated [24]. The combining effect of drivers ablation and pulmonary vein isolation (PVI) is more promising for dealing with AF. Ablation strategies for paroxysmal and persistent AF have been reviewed by many researchers, which shows a demand for complex fractionated electrograms (CFE) ablation for persistent AF along with PVI [25]. A simpler and faster ablation method with cryballoon has also been proposed [26]. Quite recently, the first simulation guided catheter ablation was reported [27].

AF is still being explored by researchers. Therefore, there is a good opportunity to contribute to AF research specially in diagnosis and ablation procedures with the use of computer simulation. The detection process and treatment of AF are still being improved to facilitate the patients more than ever. The catheter ablation procedures are continuously being developed for better efficiency. AF research combines different major areas such as signal processing, statistical techniques, simulation, algorithms, and demands their 
collaborated efforts to its modeling, diagnosis, and post-operative treatments. This is what makes it a very interesting topic for research in recent days. As each of the fields is being investigated, AF research knowledge area is being enriched simultaneously.

A brief mechanism [28] of AF can be illustrated in Figure 1. It is clear from Figure 1 how the atrial remodeling contributes to the development of chaotic signals which, in turn, causes AF.

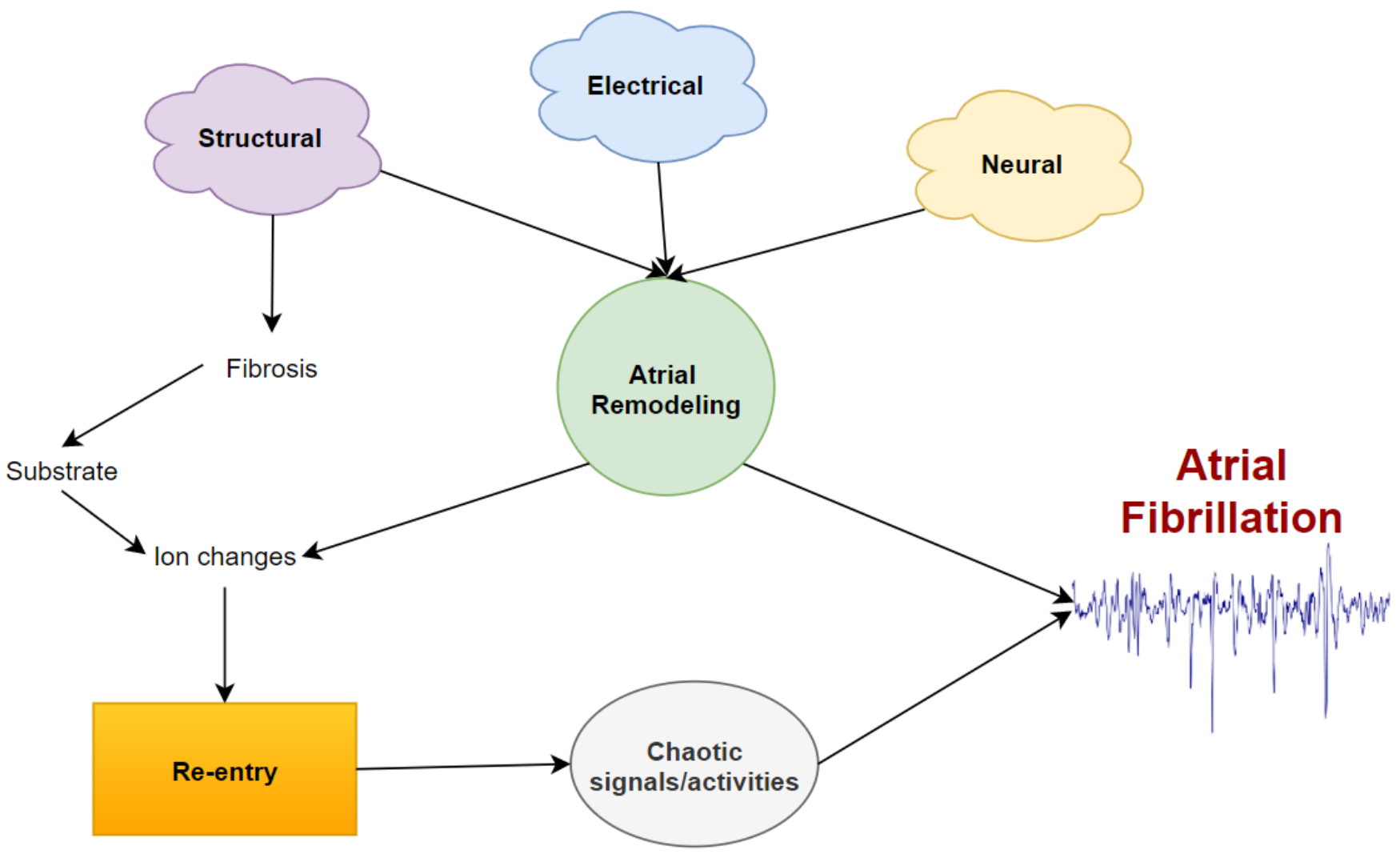

Figure 1. AF mechanism.

The primary objective of this brief literature review is to find the existing research gaps primarily in modeling, simulation, and diagnosis of AF [29-31]. There is still a need for optimized ablation procedures as stated in many articles in this field. As AF is a very important area for arrhythmia research, it demands to be well understood. The following Figure 2 shows the timeline of AF research during the past few decades.

The next section presents the overview of some important journal articles in simulation and modeling of AF followed by another section dedicated to the review of articles on rotor/trigger identification of AF diagnosis. After that section, some recent articles with emphasis on post-operative actions are reviewed. In the end, a few important research gaps and opportunities are discussed as part of concluding remarks. 


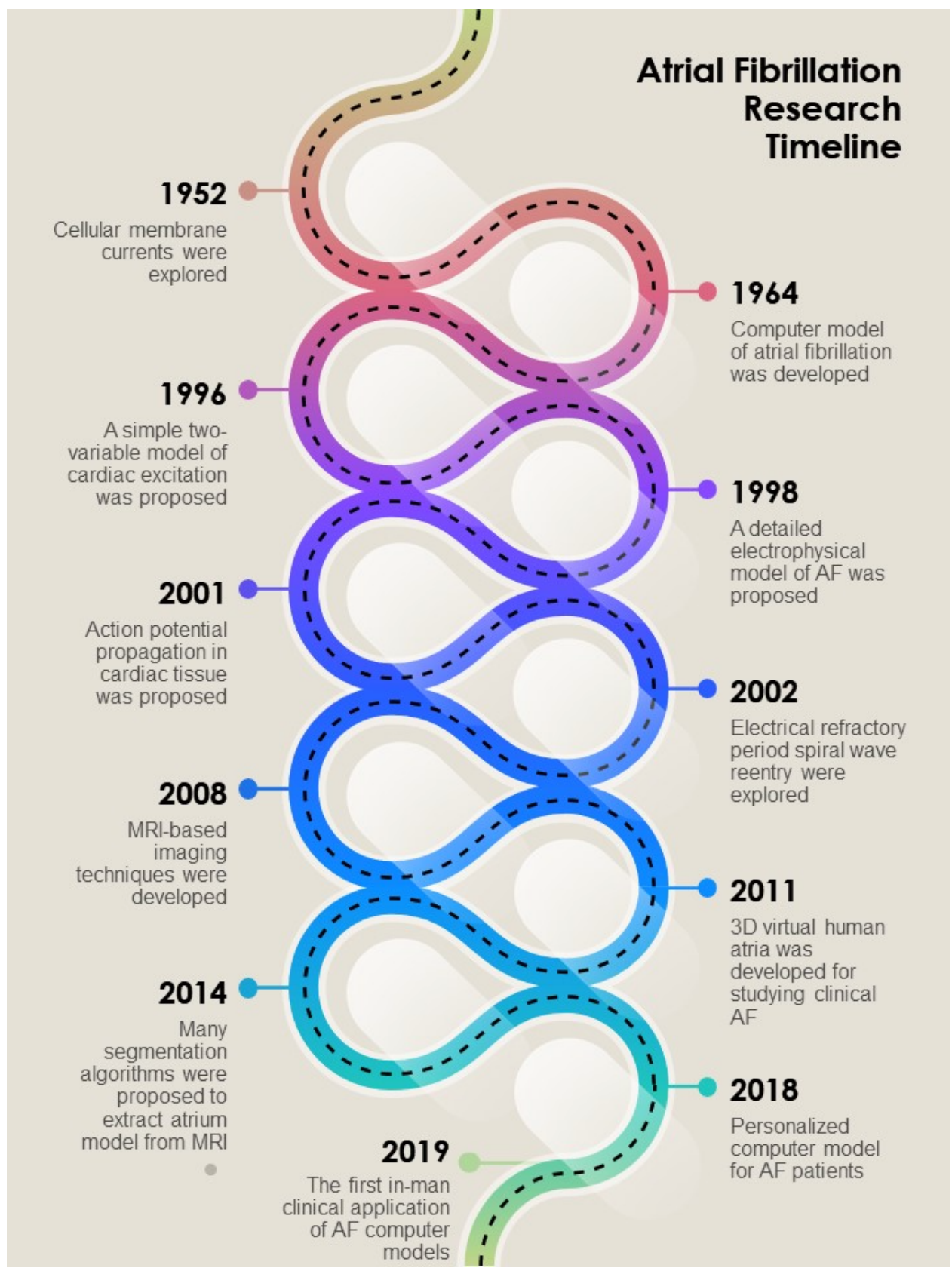

Figure 2. Atrial fibrillation research timeline.

\section{Simulation and Modeling}

Simulation and modeling have been popular in AF research for many years. Many researchers have been involved in the development of mathematical and simulation models of AF to understand it better. The first computer (cellular) model of AF was proposed back in 1964 [10]. There are basically two models widely discussed in the literature-the detailed electrical current propagation model and the simplified ( 2 variables) exponential model. The simplified model reduces the number of the large equations (as in the detailed model), and it can be solved for exact solutions. On the other hand, the detailed model is very sophisticated and characterized by its stiff equations (usually requires numerical solutions). However, it can certainly explain the electro-physiological incidents in an atrial cell much better than the reduced one. Both of these models are deterministic in nature. However, in real life, AF initiation is highly random, and thus, a stochastic modeling is more justified. Some models, however, can be very complex and computationally expensive in most cases. For simulation purposes, a good atrial mesh is necessary. Figure 3 
shows a left atrial mesh modeled from magnetic resonance imaging (MRI) data shared by comprehensive arrhythmia research and management (CARMA), Center for Integrative Biomedical Computing (CIBC) and National Institute of health (NIH).

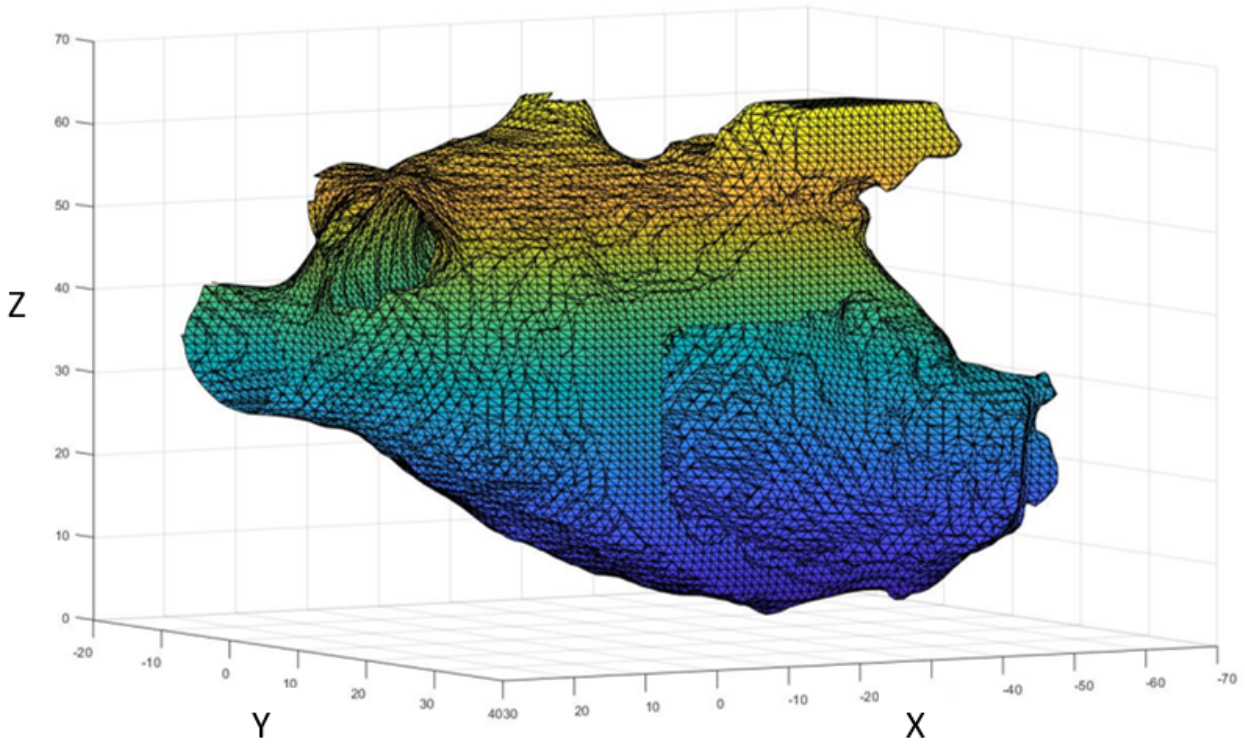

Figure 3. Three dimensional left atrial mesh generated from MRI data.

\subsection{Cellular Modeling}

Cellular automata models are usually defined by 2D square or hexagonal shapes as cells in a grid [1]. There are different stages for each cell. The classical models [10] and many others described five stages for each cell with varying refractory periods in each of them. These models are not computationally expensive, but they lack the electro-physical interaction [8] between the cells. As mentioned before, a very fundamental study [7] of membrane current initiated the ionic modeling of AF that inspired many other research initiatives $[8,11]$ on biophysically detailed cellular electro-physiological models of AF. These models use current flows through ion channels, exchangers, and pumps that are represented by ordinary differential and algebraic equations. A computer model with both left and right atria and normal electrical conduction in atrial cells has been discussed [32]. This model used computer simulation to describe the activation pattern in the atrial cells.

Another cellular model [33] that uses new Ca dynamics formulation using patient data was proposed in the literature. This model has been further used to examine the effects of $\mathrm{K}^{+}$channel protein (usually in mutated genes) on action potential (AP). All the three models are benchmarked as well [34]. However, a model based on repolarization and activation latency [35] was left out in the benchmarking as it was not published then. A brief review on different AF mathematical modeling techniques and their simulation results have also been discussed [1] in a research article. This article provides a guideline for future studies and opportunities in AF research as well. Thus, it is established that AF simulation is a well-researched topic in the literature $[1,7,8,11,12]$. As a result, there are different approaches to its computer simulation that are validated with real data. Apart from human cellular models, sheep [36-42], canine [43-47], frog [48], rabbit [49], and mice [50] models have also been discussed in the literature.

\subsection{Simulation in Atrium}

Atrial cells are modeled in most AF simulation examples. Since the generation of AF is contributed to the atrium (atrial cells) and its cellular remodeling, human atrial simulation models have been popular in the diagnosis of AF [12]. Simple 2D geometries [51,52] and quassi 3D geometric models [53] were used to model atrial cells. Human atrial action 
potential (AP) rate dependency in relation to $\mathrm{K}^{+}$is explained with simulation in atrium [54]. A computational platform is presented in the literature that is described by a $3 \mathrm{D}$ human atria [55]. This computational model can be used to study the teratogenic patterns and behavior of the electro-physical nature existing in human atria. Being inspired by this study, an approach towards the electrical remodeling in atria is proposed [56]. A realistic 3D atrial tissue model is the key indicator that an AF-induced electrical remodeling is able to produce heterogeneous and shortened action potential durations (APDs). Thus, it might be possible to initiate and maintain the reentry of excitation waves throughout the whole atrium. A similar study [57] explains the risk of electrical remodeling in atrium. The authors use the CRN model [8] to present the simulation results. Insights from a 3D model of human atria have been discussed to explain the PerAF-induced electrical remodeling [58]. The basic steps of AF simulation study are presented in Figure 4. The usual simulation process begins by defining a problem followed by data collection using image, signals, etc. To run AF simulation, a fine 3D mesh (Figure 3) is necessary with some trigger points on its surface. These trigger points denote the entry of the chaotic signals to simulate AF.

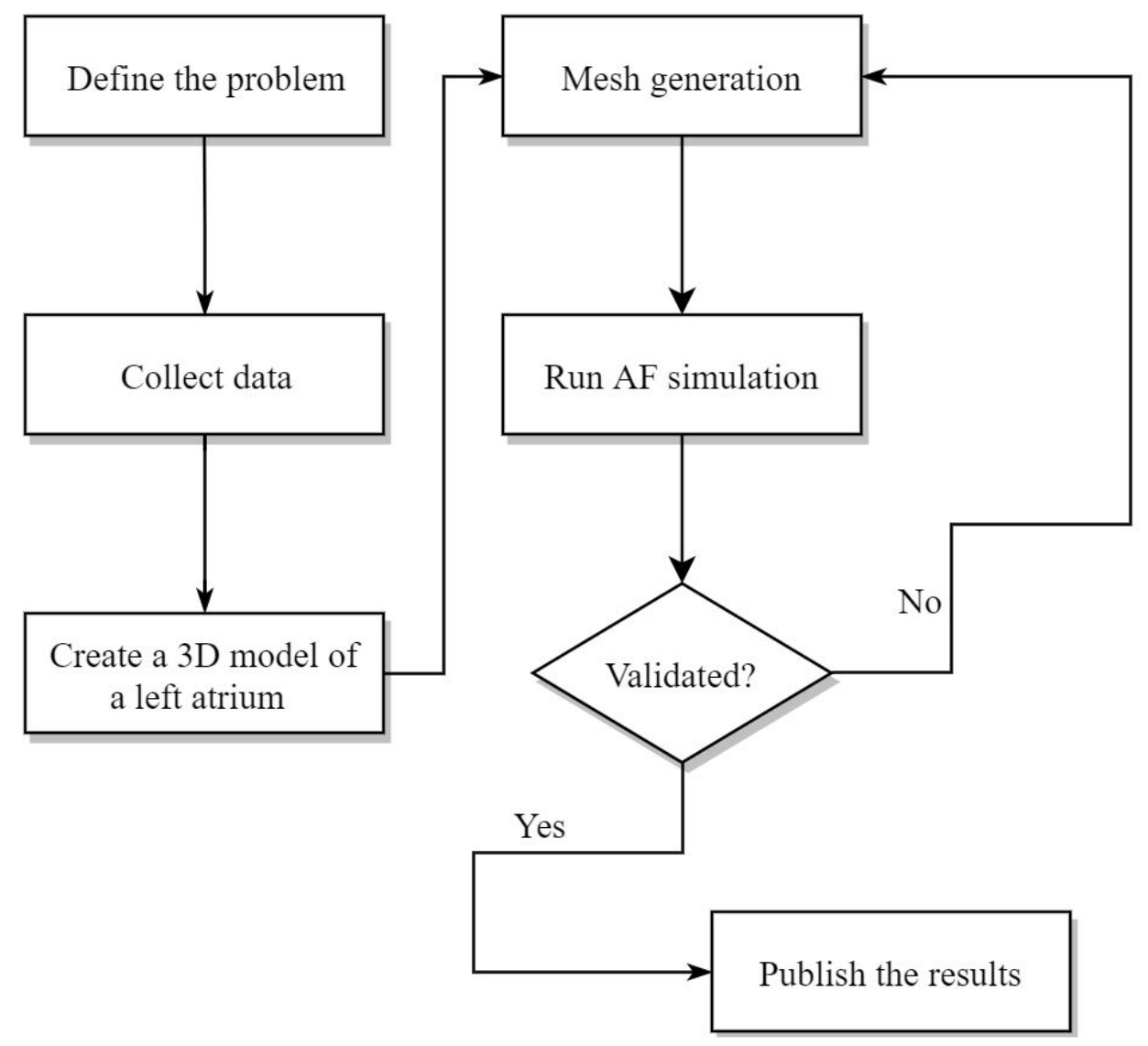

Figure 4. Basic steps of a typical AF simulation study.

\subsection{Simulation of Ablation and Clinical Observation}

Ablation is referred to a procedure that scars or destroys tissues in the heart that are responsible for chaotic signals. A preliminary simulation study with comparison of modern ablation procedures has been presented in the literature [59]. PV have been proved [60] as the trigger sites in persistent AF (PerAF) and longstanding persistent AF (LSPAF). Thus, catheter ablation is consequently an effective method to treat PerAF and LSPAF patients. In another study, localized ablation was emphasized with support from both clinical and computation study [61,62]. Some articles also discuss the evaluation of ablation patterns on according to which the ablation procedure is performed [63]. A generic 3D model was developed to aid in the diagnosis of AF with a clinical perspective [64]. A study 
reveals the use of computer simulation in terms of investigating the effects of different ablation strategies on a 3D multilayer anatomical model [65]. This study was based on 495 simulations with 23 different setups of AF initiation in a biophysical model. With all the advancement in ablation strategies till 2016, a review paper is published that shows the simulations of catheter ablation in computer models of human atria. Based on the knowledge thus far both in clinical and computational trials, six ablation targets (pulmonary vein isolation, linear ablation, ectopic foci, complex fractionated atrial electrogram, rotors, and ganglionated plexi) are considered in AF patients [66]. Customized ablation for AF patients has also been investigated by many researchers in the past decade $[67,68]$. Novel radio-frequency strategies for catheter ablation have found success as shown in a simulation study [69].

In a clinical study, older AF patients have been studied [70], and that article presents a strategy to the optimal use of anti-thrombotic therapy instead of ablation. Optimization of catheter contact force [71] and the usage of optimal ablation strategies [1] have been discussed in the literature. A mechanistic approach to ablate the drivers of AF has been proposed as well [72]. A clinical procedure involving a total of 85 patients indicated that the conventional ablation procedure (PVI) should be combined with low-voltage area (LVA) sites ablation to yield better results. Only ablation might succeed for patients with less than 10\% left atrial voltage [73]. Three-dimensional mapping of left and right atria has been explored by clinical researchers. In a study [74], the reliability of 3D mapping to represent LA, PV, and their variable branches is discussed and the authors found the process quite reliable.

As understood from the above discussion, simulation of ablation can be very helpful to treat patients with AF. However, ablation strategy demands to be investigated further. An effective and feasible design of an ablation strategy might turn out to be revolutionary in this area of research. Along with catheter ablation, some patients are treated with mazed ablation as well. The following sections have more detailed discussion on AF treatment with ablation and associated aspects of recovery.

\section{Rotor/Trigger Identification}

To diagnose $\mathrm{AF}$, rotor or trigger identification is very important due to the complex nature of atrial cell mechanism. A simple model to identify the critical regions in AF is proposed that uses wave front propagation on an anisotropic structure mimicking the branching network of heart muscle cells [75]. Fibrosis, anisotropy, refractory period, and stimulus location mostly determine the rotor formation as suggested by an automaton model developed to explain the rotational activities during AF [76]. There are many articles that propose the use of dominant frequency (also signal processing methods) to detect the rotors or triggers of AF $[17,18,36-38,77-84]$. Apart from these, many wave propagation techniques have been explored [19,85-88]. Some articles even use image-based techniques to detect rotor or trigger [89-92]. Sarcoplasmic reticulum $\mathrm{Ca}^{2+}$ leak and after depolarization-triggered activity can also act as catalysts for cellular arrythmogenesis in persistent AF patients [4,5]. One significant study [93] aims to evaluate and compare a total of nine different AF detection algorithms based on electrocardiogram (ECG) signals. These algorithms were developed by analyzing two characteristics of ECG, namely RR (peak to peak) interval irregularity (RRI) and chaotic atrial activity (AA). All of the nine algorithms are based on either RRI or AA characteristics. However, the comparative analysis performed in the study indicates that the combination of both these characteristics might result in a better algorithm to obtain more effective results. Machine learning methods to detect AF driver location are also investigated in recent studies [94]. Activation patterns during AF in an experimental model are also investigated with the help of ECG [95]. Electro-anatomic maps based on dynamic approximate entropy have been used to detect rotors in a simulation study of 3D human atrium [96]. With the advancement of smart phone technology, photoplethysmography (PPG), [97] camera apps [98], etc., have been 
used. Sample datasets were obtained from smart phones using Android OS by Google Inc., Mountain View, CA, USA.

\subsection{Dominant Frequency (DF) and Signal Processing (SP)}

A real-time DF (Dominant Frequency) ablation with radio-frequency mapping is proposed [17] to maintain the sinus rhythm in paroxysmal AF patients. This ablation procedure eliminates the left-to-right atrium frequency gradients [18] and predicts a high probability for a long-term sinus rhythm maintenance of AF patients. A very recent study [78]) introduces a new tool called regional dominant frequency (RDF) for wave break rate (WBR) identification during AF. According to the study, these two metrics are weakly correlated. An investigation should be conducted to see whether a critical dominant frequency is sufficient end point for radio frequency ablation (RFA) so that a patient might not need to go for complete ablation. According to them, a decrease of more than $11 \%$ in the dominant frequency (using Antral pulmonary vein isolation and complex fractionated atrial electrogram a.k.a. CFAE) can ensure the maintenance of sinus rhythm in persistent $\mathrm{AF}$ patients [77]. A similar article [79] showed that the role of high DF in non-paroxysmal AF patients is vital. These patients tend to respond well to pulmonary vein isolation and thereafter complex fractionated electrogram ablation. A simulation-based study on sheep atrium is described in [36] that mainly focuses on the formation of rotors and its impact in AF. This study, though not totally transferable in human cases, might be able to explain the persistent $\mathrm{AF}$ in human atria. The mechanism of wave fractionation in isolated sheep heart is explained as well [37]. In addition, the dominant frequency increase rate can be a good indicator of the transition from paroxysmal to long-term persistent AF in a sheep heart [38].

\subsection{Wave Propagation (WP)}

Wave propagation direction has been investigated with mathematical analysis of vector field [19], conduction velocity estimation [85-87], electrocardiography-gated phase contrast MRI [88], and many other mathematical approaches. These approaches have certain benefits and disadvantages while being used for particular problems. A list with all these information is provided [87] to present a comparative analysis. Among the approachestriangulation and finite difference use actual local activation times (LAT) for velocity estimation but are somewhat difficult to automate being sensitive to LAT errors. Vector loops and radial basis approaches require specific catheter ( 2 orthogonal pairs of bipole) and huge computational power, respectively. Analytical approach, being easy to be applied, requires the meshing points to lie on a well defined geometrical shape (e.g., square, radius of curvature, etc.). However, several open questions are left unanswered [87] specially about the uncertainty estimation in conduction velocity computation (more specifically, the propagation of wavelets in a 3D tissue using 2D surface measurement and algorithms). A quantitative single-shot approach [85] to extract the wave direction and local conduction velocity from one single beat has been discussed in the literature. Vector analysis with curl and divergent operations to find the velocity direction is used in [19]. Based on some assumptions for sequential mapping in cardiac conduction velocity, an estimation method is proposed [86]. The estimation errors were modeled with known Gaussian distribution. A qualitative propagation model based on stochastic individual data for $\mathrm{AF}$ has been described in the literature recently [99].

\section{Biledical Image Processing}

Image-based rotor or trigger identification techniques have been well explored in the literature [100-105]. Among the techniques, magnetic resonance imaging (MRI) has been perhaps one of the most popular ones [106], specially delay-enhancement MRI [102,107,108]. In recent years, many segmentation techniques have been applied to extract the LA from MRI images [109-117]. A noninvasive MRI method was introduced [101] to detect the left atrial injury after catheter ablation. This study concluded with an apparent indication of correlation between the LA wall injury (after ablation) and short-term procedural outcome 
for AF patients. Risk assessment of stroke in AF patients and detection of left atrial fibrosis (also [107]) with MRI are discussed briefly [102]. In relation to that study, it is found that the patients with undetermined strokes have increased atrial fibrosis [106]. Another article [103] provides a methodology to detect atrial fibrosis of persistent AF patients using cardiovascular magnetic resonance imaging (CMR). Magnetic resonance angiography was used for PV dilation for both paroxysmal and chronic AF patients [100]. It was found that the LA enlargement with significant dilation of superior PV occurred in both types of AF patients. As a part of recent research involving AF rotors, the visualization of individual relationship between electric rotors from noninvasive mapping and atrial fibrosis with the help of a new algorithm was proposed in 2018 [118]. In another study, reference [105] high-resolution electro-cardiogram imaging (ECGI) was applied for the assessment of the relationship between atrial fibrosis and persistent AF.

A very important step for successful implementation of imaging techniques to extract the LA is image segmentation. Review articles on image segmentation are frequently observed in the literature recently. There have been many methods proposed for image segmentation [119-124]. These articles focus on image segmentation by using multi-objective optimization [121,124], machine learning [122], evolutionary algorithms [119,120], clusters $[112,123]$, and other tools. Image segmentation is primarily used to isolate the LA (or other segments of the heart) from the MRI data of the whole heart. Thus, the segmentation method can be challenging to implement if the images from MRI do not have a good resolution. Another difficulty while dealing with MRI slices is that the intensity of soft tissues is not significantly different than that of the bones. Thus, it cannot be easily detected by conventional algorithms based on contrast or intensity.

\section{Image Segmentation}

Image segmentation is a broad concept and has been investigated by researchers from different fields. It is defined as the process that partitions a picture or image into distinctive subsets. The most basic attributes used for image segmentation are-intensity, edges, textures, etc. First, the object's whereabouts in the image are to be determined (called recognition). Then, the object's spatial extent and composition in the scene are extracted (called delineation). Thus, recognition allows the information flow from humans to computer, and delineation allows the information flow from computer to humans. Both processes are integral to a successful image segmentation. In the next paragraphs, recognition and delineation are discussed in detail. There are many approaches to object recognition, but they fall into two broad categories-interactive and non-interactive. As shown in Figure 5, non-interactive approaches involve model, knowledge, and atlasbased recognition while interactive approaches mostly involve human-assisted recognition. Figure 5 also shows different approaches towards image delineation.

There are some merits and demerits of PI and SM approaches. Table 1 shows their comparative analysis.

Table 1. Comparison between PI and SM based image segmentation.

\section{Purely Image (PI) Based Image Segmentation}

\section{Merits}

It works well when image information is good. It can determine degree of match of model to image. It does not require best match information

\section{Demerits}

It does not do well if image information is bad/absent.

It cannot perform recognition well.

It generally lacks object shape and information.

\section{Shape Model (SM)-Based Image Segmentation}

\section{Merits}

Model might work well even if the image info is bad.

It helps with image recognition

Good model has object shape and geographic info

\section{Demerits}

Accuracy might suffer even with good image info.

It generally requires best match info.

It might not be suitable for object delineation 


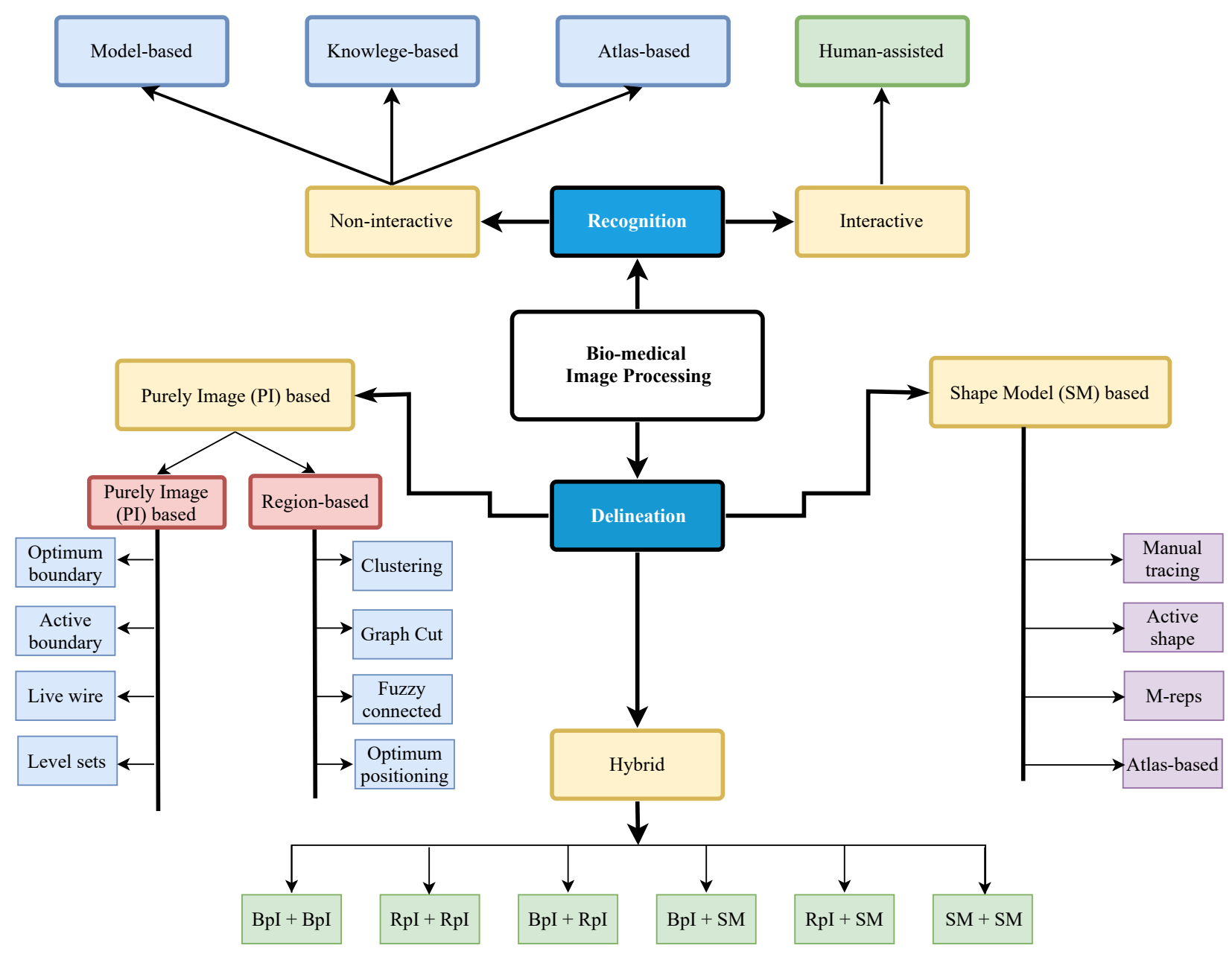

Figure 5. Image recognition and delineation classes.

To date, numerous post-processing software packages have been used (specially in MRI imaging) such as 3D slicer, Neusoft, mediCAD, SPECT, gr-MRI, etc.

\section{Post-Treatment Actions}

After an AF patient is treated, there can be several complications that might even lead to death. Therefore, the post-operative actions are required to be advised carefully. Statistical analysis shows the correlation between different factors (age, gender, race, recurrence, and health condition) of AF patients. When an AF patient is treated with ablation, cardiac rhythm control becomes very important for the recovery. Rhythm control represents the acute restoration and maintenance of sinus rhythm [125]. However, recurrent AF patients usually need further investigation to maintain the long-term sinus rhythm. A pharmacistled algorithm is presented in [70] that helps to ensure better anti-thrombotic therapy for elderly patients. The following two sections provide a brief overview of statistical analysis used in $\mathrm{AF}$, followed by a brief review of journal articles focused on cardiac rhythm control and maintenance.

\subsection{Statistical Analysis}

Statistical analysis involving patients with AF has been investigated by many researchers. Using statistical estimation techniques, the frequency gradient $\left(\mathrm{DF}_{\max }\right)$ is found to be the only significant factor among others (e.g., age, gender, hypertension, proportion of non-PV triggers, etc.) that varied among three different groups of patients [79] treated with CFE ablation. It has been reported in [126] that the number of patients with AF increased $60 \%$ during the last decade when the article was published. This establishes a 
historical trend of the increasing number of AF patients. A more recent study [127] presents the complications after AF ablation among a group of patients in 23 states of the United States. A statistical analysis on mobile cardiac outpatient telemetry (MCOT) to detect AF is discussed [128]. This article emphasized on the MCOT to detect brief (less than $30 \mathrm{~s}$ ) AF episodes as they can easily lead to stroke [128]. Paroxymal AF diagnosis by pulmonary vein isolation (PVI) has been investigated in [71]. In their study, it has been statistically proven that the optimization of catheter contact force during AF ablation improves the outcome of PVI. Electrogram morphology recurrence patterns have been discussed [129] to show their effect during AF. Another study on a total of 589 persistent AF patients supports the fact that there is no difference in the rate of recurrent $\mathrm{AF}$ between linear ablation and ablation of fractionated electrograms with PVI [130]. A statistical trial named atrial fibrillation follow-up investigation of rhythm management (AFFIRM) is used [131] for two sample t-test and chi-squared tests to compare the effects of crossover from rhythm to rate and rate to rhythm control therapy in AF patients. An interesting study [132] presents a parametric nonlinear mixed effects model to find the probability of AF after ablation.

\subsection{Cardiac Rhythm Control and Maintenance}

As the early recurrence of AF is common these days, the cardiac rhythm maintenance is of high importance. Catheter ablation proves to be more effective than antiarrhythmic drug therapy in some patients [125]. However, there are some major complications (such as delayed pericardial tamponade, atrio-oesophageal fistula formation, fever, etc.) associated with it. Thus, the common approach is to treat the AF patients with drug therapy first, and if this does not help, catheter ablation procedure is initiated to control the sinus rhythm. An important comparative analysis [133] shows the effectiveness on mortality between rate control drug (Also [134]) and rhythm control therapy in AF patients. However, another study [135] claims that neither of these two strategies has any competitive advantage over the other. In another study (previously mentioned), the AFFIRM trial [131] presents the impact of treatment crossovers on clinical outcomes in the rate and rhythm control strategies.

The effects of anti-arrhythmic drug versus no anti-arrhythmic treatment has also been analyzed with a systematic review of articles published between 2008 and 2012 [136]. Although the post-operative AF was not considered in that review, the article provides a guideline to analyze the effects of antiarrhythmic treatment in long term until sinus rhythm is restored. A drug named Dofetilide is commonly used in the United States as a rhythm control strategy of AF [137]. Amiodarone (another drug) is also used (although it might be toxic) as an alternative to ablation is some cases [138] as a rate control strategy specially in patients for whom other anti-arrhythmic drugs are unavailable. However, the study indicates the superiority of catheter ablation (rhythm control) over amiodarone (rate control). Ranolazine (another rhythm maintenance drug) has been used to clinical experiments to reduce AF $[139,140]$. In clinically relevant large animal heart AF models, TREK-1 $\left(\mathrm{K}_{2 \mathrm{p}} 2.1\right)$ Potassium (cation) channels effectively provide rhythm control [141]. Simulation of ventricular rate control [142] and patient-specific sinus rhythm maintenance [143] have been investigated. In order to implement any cardioversion or rhythm control of $\mathrm{AF}$ in high-risk patients, the appropriate precautionary and safety measures are to be taken [144] that have been presented in a research document lately. An attempt to explore the potential maintenance mechanism in atrial fibrillation patients (treated with different ablation strategies) was introduced very recently [145]. Prediction models have been used to detect the incident of $\mathrm{AF}$ and its maintenance in Japanese people very recently [146]. In a recent study, the medical, psychological, and behavioral aspects of AF management have been discussed [147].

\section{Limitations}

Like any other study, this research has some limitations. It is very difficult to accommodate the details of all the published articles that discusses AF research in the literature. 
Since AF itself is a complex phenomenon, its research approaches are diverse. In simulation studies, the researchers work on modeling AF and use different methods for trigger identification. Thus, there are numerous articles that analyze AF simulation studies over the past few years or even decades. As for the clinical studies, there are also many articles published each year that analyze AF treatment, diagnosis, and post-operative rhythm maintenance. With these facts in mind, this review article aimed to cover most important AF research studies throughout the years. However, it is quite natural that some studies might not have been included.

\section{Conclusions and Future Scopes}

This article is intended to discuss the chronological progress in AF research through a comprehensive review of journal articles. It is important to know how AF has been investigated by many researchers for the past few decades. This study indicates some important areas (such as AF detection and diagnosis) where the research gaps exist in this field. Although the initiation of AF can be totally random, there is hardly any article (except a few) with stochastic modeling approach for the propagation of AF. Therefore, this is a potential research gap worth investigating in the near future. Although the stochastic modeling of the detailed cellular model might be computationally expensive, the stochastic approach to develop a robust AF simulation with the simplified model can be useful to improve the computation time. As this article has shown that there are still many causes for $\mathrm{AF}$ that are unknown to the researchers, with the advancement in medical imaging and technology, the underlying causes of AF are hoped to be revealed gradually.

As this study suggests, the rotor/trigger identification might be very important for the diagnosis of AF. In the literature, there are few articles that demonstrate the use of machine learning algorithms (such as decision forests, nearest neighbors, and k-means clustering) to identify the rotor or trigger of AF. The authors expect that machine learning (artificial intelligence) or data analytical algorithm will also be useful as detection mechanisms in future. Apart from this, the region of affected atrial cells (causing AF) may be detected by formulating a combinatorial optimization problem. Thus, there may be several research directions to improve AF detection and diagnosis.

Catheter ablation is another vital area to be explored further. As can be seen from this comprehensive review, there is still the need for a customized and clinically efficient catheter ablation strategy for paroxysmal and persistent AF patients. Although the maze procedures gained popularity in recent times, it is still not enough to meet the requirements of complete elimination and possible recurrence of AF. It is undoubtedly evident that atrial modeling holds the key to future diagnosis and prevention of AF in human heart. Therefore, AF research should be spread and supported widely.

Author Contributions: Conceptualization, M.A.U.Z. and D.D.; methodology, M.A.U.Z.; software, M.A.U.Z.; validation, M.A.U.Z. and D.D.; formal analysis, M.A.U.Z.; writing-original draft preparation, M.A.U.Z.; writing—review and editing, M.A.U.Z.; visualization, M.A.U.Z.; supervision, D.D. All authors have read and agreed to the published version of the manuscript.

Funding: This research received no external funding.

Conflicts of Interest: The authors declare no conflict of interest.

\section{References}

1. Trayanova, N.A. Mathematical approaches to understanding and imaging atrial fibrillation: Significance for mechanisms and management. Circ. Res. 2014, 114, 1516-1531. [CrossRef] [PubMed]

2. Nattel, S.; Harada, M. Atrial remodeling and atrial fibrillation: Recent advances and translational perspectives. J. Am. Coll. Cardiol. 2014, 63, 2335-2345. [CrossRef] [PubMed]

3. Iwasaki, Y.K.; Nishida, K.; Kato, T.; Nattel, S. Atrial fibrillation pathophysiology: Implications for management. Circulation 2011, 124, 2264-2274. [CrossRef] [PubMed]

4. Voigt, N.; Heijman, J.; Wang, Q.; Chiang, D.Y.; Li, N.; Karck, M.; Dobrev, D. Cellular and molecular mechanisms of atrial arrhythmogenesis in patients with paroxysmal atrial fibrillation. Circulation 2014, 129, 145-156. [CrossRef] [PubMed] 
5. Heijman, J.; Voigt, N.; Nattel, S.; Dobrev, D. Cellular and molecular electrophysiology of atrial fibrillation initiation, maintenance, and progression. Circ. Res. 2014, 114, 1483-1499. [CrossRef] [PubMed]

6. Zaman, J.A.; Sauer, W.H.; Alhusseini, M.I.; Baykaner, T.; Borne, R.T.; Kowalewski, C.A.; Wang, P.J. Identification and characterization of sites where persistent atrial fibrillation is terminated by localized ablation. Circ. Arrhythmia Electrophysiol. 2018, 11, e005258. [CrossRef]

7. Hodgkin, A.L.; Huxley, A.F. A quantitative description of membrane current and its application to conduction and excitation in nerve. J. Physiol. 1952, 117, 500-544. [CrossRef]

8. Courtemanche, M.; Ramirez, R.J.; Nattel, S. Ionic mechanisms underlying human atrial action potential properties: Insights from a mathematical model. Am. J. Physiol. Heart Circ. Physiol. 1998, 275, H301-H321. [CrossRef]

9. Nygren, A.; Leon, L.J.; Giles, W.R. Simulations of the human atrial action potential. Philos. Trans. R. Soc. Lond. A Math. Phys. Eng. Sci. 2001, 359, 1111-1125. [CrossRef]

10. Moe, G.K.; Rheinboldt, W.C.; Abildskov, J.A. A computer model of atrial fibrillation. Am. Heart J. 1964, 67, 200-220. [CrossRef]

11. Du, D.; Du, Y. Detection of the propagating direction of electrical wavefront in atrial fibrillation. In Proceedings of the 2016 38th Annual International Conference of the IEEE Engineering in Medicine and Biology Society (EMBC), Orlando, FL, USA, 16-20 August 2016 ; pp. 2749-2752.

12. Simitev, R.D.; Biktashev, V.N. Conditions for propagation and block of excitation in an asymptotic model of atrial tissue. Biophys. J. 2006, 90, 2258-2269. [CrossRef] [PubMed]

13. Krogh-Madsen, T.; Abbott, G.W.; Christini, D.J. Effects of electrical and structural remodeling on atrial fibrillation maintenance: A simulation study. PLoS Comput. Biol. 2012, 8, e1002390. [CrossRef] [PubMed]

14. Jacquemet, V.; Virag, N.; Kappenberger, L. Wavelength and vulnerability to atrial fibrillation: Insights from a computer model of human atria. EP Eur. 2005, 7, S83-S92. [CrossRef] [PubMed]

15. Lin, Y.T.; Chang, E.T.; Eatock, J.; Galla, T.; Clayton, R.H. Mechanisms of stochastic onset and termination of atrial fibrillation studied with a cellular automaton model. J. R. Soc. Interface 2017, 14, 20160968. [CrossRef]

16. McDowell, K.S.; Vadakkumpadan, F.; Blake, R.; Blauer, J.; Plank, G.; MacLeod, R.S.; Trayanova, N.A. Mechanistic inquiry into the role of tissue remodeling in fibrotic lesions in human atrial fibrillation. Biophys. J. 2013, 104, 2764-2773. [CrossRef]

17. Atienza, F.; Almendral, J.; Jalife, J.; Zlochiver, S.; Ploutz-Snyder, R.; Torrecilla, E.G.; Berenfeld, O. Real-time dominant frequency mapping and ablation of dominant frequency sites in atrial fibrillation with left-to-right frequency gradients predicts long-term maintenance of sinus rhythm. Heart Rhythm. 2009, 6, 33-40. [CrossRef]

18. Lazar, S.; Dixit, S.; Callans, D.J.; Lin, D.; Marchlinski, F.E.; Gerstenfeld, E.P. Effect of pulmonary vein isolation on the left-to-right atrial dominant frequency gradient in human atrial fibrillation. Heart Rhythm. 2006, 3, 889-895. [CrossRef]

19. Fitzgerald, T.N.; Brooks, D.H.; Triedman, J.K. Identification of cardiac rhythm features by mathematical analysis of vector fields. IEEE Trans. Biomed. Eng. 2005, 52, 19-29. [CrossRef]

20. Deedwania, P.C.; Lardizabal, J.A. Atrial fibrillation in heart failure: A comprehensive review. Am. J. Med. 2010, 123, 198-204. [CrossRef]

21. Rodrigo, M.; Climent, A.M.; Liberos, A.; Fernandez-Aviles, F.; Berenfeld, O.; Atienza, F.; Guillem, M.S. Atrial sources identification by causality analysis during atrial fibrillation. In Proceedings of the 2015 37th Annual International Conference of the IEEE Engineering in Medicine and Biology Society (EMBC), Milan, Italy, 25-29 August 2015; pp. 3783-3786.

22. Kirchhof, P.; Camm, A.J.; Goette, A.; Brandes, A.; Eckardt, L.; Elvan, A.; Breithardt, G. Early rhythm-control therapy in patients with atrial fibrillation. N. Engl. J. Med. 2020, 383, 1305-1316. [CrossRef]

23. Ganesan, A.N.; Shipp, N.J.; Brooks, A.G.; Kuklik, P.; Lau, D.H.; Lim, H.S.; Sanders, P. Long-term outcomes of catheter ablation of atrial fibrillation: A systematic review and meta-analysis. J. Am. Heart Assoc. 2013, 2, e004549. [CrossRef] [PubMed]

24. Baykaner, T.; Rogers, A.J.; Meckler, G.L.; Zaman, J.; Navara, R.; Rodrigo, M.; Clopton, P. Clinical implications of ablation of drivers for atrial fibrillation: A systematic review and meta-analysis. Circ. Arrhythmia Electrophysiol. 2018, 11, e006119. [CrossRef] [PubMed]

25. Verma, A. The techniques for catheter ablation of paroxysmal and persistent atrial fibrillation: A systematic review. Curr. Opin. Cardiol. 2011, 26, 17-24. [CrossRef] [PubMed]

26. Andrade, J.G.; Khairy, P.; Guerra, P.G.; Deyell, M.W.; Rivard, L.; Macle, L.; Dubuc, M. Efficacy and safety of cryoballoon ablation for atrial fibrillation: A systematic review of published studies. Heart Rhythm. 2011, 8, 1444-1451. [CrossRef]

27. Boyle, P.M.; Zghaib, T.; Zahid, S.; Ali, R.L.; Deng, D.; Franceschi, W.H.; Trayanova, N.A. Computationally guided personalized targeted ablation of persistent atrial fibrillation. Nat. Biomed. Eng. 2019, 3, 870-879. [CrossRef]

28. Wijesurendra, R.S.; Casadei, B. Mechanisms of atrial fibrillation. Heart 2019, 105, 1860-1867. [CrossRef]

29. Bifulco, S.F.; Akoum, N.; Boyle, P.M. Translational applications of computational modelling for patients with cardiac arrhythmias. Heart 2021, 107, 456-461. [CrossRef]

30. Corrado, C.; Avezzù, A.; Lee, A.W.; Mendoca Costa, C.; Roney, C.H.; Strocchi, M.; Niederer, S.A. Using cardiac ionic cell models to interpret clinical data. WIREs Mech. Dis. 2021, 13, e1508. [CrossRef]

31. Heijman, J.; Sutanto, H.; Crijns, H.J.; Nattel, S.; Trayanova, N.A. Computational models of atrial fibrillation: Achievements, challenges, and perspectives for improving clinical care. Cardiovasc. Res. 2021, 117, 1682-1699. [CrossRef]

32. Harrild, D.M.; Henriquez, C.S. A computer model of normal conduction in the human atria. Circ. Res. 2000, 87, 25-36. 
33. Grandi, E.; Pandit, S.V.; Voigt, N.; Workman, A.J.; Dobrev, D.; Jalife, J.; Bers, D.M. Human atrial action potential and Ca ${ }^{2+}$ model: Sinus rhythm and chronic atrial fibrillation. Circ. Res. 2011, 109, 1055-1066. [CrossRef] [PubMed]

34. Wijffels, M.C.; Kirchhof, C.J.; Dorland, R.; Allessie, M.A. Atrial fibrillation begets atrial fibrillation: A study in awake chronically instrumented goats. Circulation 1995, 92, 1954-1968. [CrossRef] [PubMed]

35. Krummen, D.E.; Bayer, J.D.; Ho, J.; Ho, G.; Smetak, M.R.; Clopton, P.; Narayan, S.M. Mechanisms of human atrial fibrillation initiation: Clinical and computational studies of repolarization restitution and activation latency. Circ. Arrhythmia Electrophysiol. 2012, 5, 1149-1159. [CrossRef] [PubMed]

36. Berenfeld, O.; Jalife, J. Mechanisms of atrial fibrillation: Rotors, ionic determinants, and excitation frequency. Heart Fail. Clin. 2016, 12, 167-178. [CrossRef] [PubMed]

37. Kalifa, J.; Tanaka, K.; Zaitsev, A.V.; Warren, M.; Vaidyanathan, R.; Auerbach, D.; Atienza, F. Mechanisms of wave fractionation at boundaries of high-frequency excitation in the posterior left atrium of the isolated sheep heart during atrial fibrillation. Circulation 2006, 113, 626-633. [CrossRef] [PubMed]

38. Martins, R.P.; Kaur, K.; Hwang, E.; Ramirez, R.J.; Willis, B.C.; Filgueiras-Rama, D.; O'connell, R.P. Dominant frequency increase rate predicts transition from paroxysmal to long-term persistent atrial fibrillation. Circulation 2014, 129, 1472. [CrossRef]

39. Addis, A.; Vanosi, G.; Manasse, E.; Mainetti, M.; Monaco, A.; Addis, F. An experimental sheep model used to develop an ablation procedure for chronic atrial fibrillation. Surg. Endosc. 2007, 21, 1626-1630. [CrossRef]

40. Butters, T.D.; Aslanidi, O.V.; Zhao, J.; Smaill, B.; Zhang, H. A novel computational sheep atria model for the study of atrial fibrillation. Interface Focus 2013, 3, 20120067. [CrossRef]

41. Doll, N.; Kornherr, P.; Aupperle, H.; Fabricius, A.M.; Kiaii, B.; Ullmann, C.; Mohr, F.W. Epicardial treatment of atrial fibrillation using cryoablation in an acute off-pump sheep model. Thorac. Cardiovasc. Surg. 2003, 51, 267-273. [CrossRef]

42. Doll, N.; Suwalski, P.; Aupperle, H.; Walther, T.; Borger, M.A.; Schoon, H.A.; Mohr, F.W. Endocardial laser ablation for the treatment of atrial fibrillation in an acute sheep model. J. Card. Surg. 2008, 23, 198-203. [CrossRef]

43. Everett, T.H.T.; Li, H.; Mangrum, J.M.; McRury, I.D.; Mitchell, M.A.; Redick, J.A.; Haines, D.E. Electrical, morphological, and ultrastructural remodeling and reverse remodeling in a canine model of chronic atrial fibrillation. Circulation 2000, 102, 1454-1460. [CrossRef] [PubMed]

44. Fedorov, V.V.; Sharifov, O.F.; Beloshapko, G.G.; Yushmanova, A.V.; Rosenshtraukh, L.V. Effects of a new class III antiarrhythmic drug nibentan in a canine model of vagally mediated atrial fibrillation. J. Cardiovasc. Pharmacol. 2000, 36, 77-89. [CrossRef] [PubMed]

45. Goldberg, A.; Kusunose, K.; Qamruddin, S.; Rodriguez, L.L.; Mazgalev, T.N.; Griffin, B.P.; Van Wagoner, D.R.; Zhang, Y.; Popovic, Z.B. Left Atrial Size and Function in a Canine Model of Chronic Atrial Fibrillation and Heart Failure. PLoS ONE 2016, 11, e0147015. [CrossRef] [PubMed]

46. Tang, M.; Zhang, S.; Sun, Q.; Huang, C. Alterations in electrophysiology and tissue structure of the left atrial posterior wall in a canine model of atrial fibrillation caused by chronic atrial dilatation. Circ. J. 2007, 71, 1636-1642. [CrossRef] [PubMed]

47. Yue, L.; Feng, J.; Gaspo, R.; Li, G.R.; Wang, Z.; Nattel, S. Ionic remodeling underlying action potential changes in a canine model of atrial fibrillation. Circ. Res. 1997, 81, 512-525. [CrossRef] [PubMed]

48. Rasmusson, R.L.; Clark, J.W.; Giles, W.R.; Robinson, K.; Clark, R.B.; Shibata, E.F.; Campbell, D.L. A mathematical model of electrophysiological activity in a bullfrog atrial cell. Am. J. Physiol. Heart Circ. Physiol. 1990, 259, H370-H389. [CrossRef]

49. Hilgemann, D.W.; Noble, D. Excitation-contraction coupling and extracellular calcium transients in rabbit atrium: Reconstruction of basic cellular mechanisms. Proc. R. Soc. Lond. B 1987, 230, 163-205.

50. Bukowska, A.; Felgendreher, M.; Scholz, B.; Wolke, C.; Schulte, J.S.; Fehrmann, E.; Wardelmann, E.; Seidl, M.D.; Lendeckel, U.; Himmler, K.; et al. CREM-transgene mice: An animal model of atrial fibrillation and thrombogenesis. Thromb. Res. 2018, 163, 172-179. [CrossRef]

51. Kneller, J.; Zou, R.; Vigmond, E.J.; Wang, Z.; Leon, L.J.; Nattel, S. Cholinergic atrial fibrillation in a computer model of a two-dimensional sheet of canine atrial cells with realistic ionic properties. Circ. Res. 2002, 90, e73-e87. [CrossRef]

52. Correa de Sa, D.D.; Thompson, N.; Stinnett-Donnelly, J.; Znojkiewicz, P.; Habel, N.; Müller, J.G.; Spector, P.S. Electrogram fractionation: The relationship between spatiotemporal variation of tissue excitation and electrode spatial resolution. Circ. Arrhythmia Electrophysiol. 2011, 4, 909-916. [CrossRef]

53. Kuo, S.R.; Trayanova, N.A. Action potential morphology heterogeneity in the atrium and its effect on atrial reentry: A twodimensional and quasi-three-dimensional study. Philos. Trans. R. Soc. Lond. A Math. Phys. Eng. Sci. 2006, 364, 1349-1366. [CrossRef] [PubMed]

54. Maleckar, M.M.; Greenstein, J.L.; Giles, W.R.; Trayanova, N.A. $\mathrm{K}^{+}$current changes account for the rate dependence of the action potential in the human atrial myocyte. Am. J. Physiol. Heart Circ. Physiol. 2009, 297, H1398-H1410. [CrossRef] [PubMed]

55. Aslanidi, O.V.; Colman, M.A.; Stott, J.; Dobrzynski, H.; Boyett, M.R.; Holden, A.V.; Zhang, H. 3D virtual human atria: A computational platform for studying clinical atrial fibrillation. Prog. Biophys. Mol. Biol. 2011, 107, 156-168. [CrossRef] [PubMed]

56. Colman, M.A.; Aslanidi, O.V.; Kharche, S.; Boyett, M.R.; Garratt, C.; Hancox, J.C.; Zhang, H. Pro-arrhythmogenic effects of atrial fibrillation-induced electrical remodeling: Insights from the three dimensional virtual human atria. J. Physiol. 2013, 591, 4249-4272. [CrossRef] [PubMed]

57. Seemann, G.; Bustamante, P.C.; Ponto, S.; Wilhelms, M.; Scholz, E.P.; Dössel, O. Atrial fibrillation-based electrical remodeling in a computer model of the human atrium. Comput. Cardiol. 2010, 37, 417-420. 
58. Adeniran, I.; MacIver, D.H.; Garratt, C.J.; Ye, J.; Hancox, J.C.; Zhang, H. Effects of Persistent Atrial Fibrillation-Induced Electrical Remodeling on Atrial Electro-Mechanics-Insights from a 3D Model of the Human Atria. PLoS ONE 2015, 10, e0142397. [CrossRef]

59. Gong, Y.; Gao, Y.; Lu, Z.; Zheng, D.; Deng, D.; Xia, L. Preliminary simulation study of atrial fibrillation treatment procedure based on a detailed human atrial model. J. Clin. Trial. Cardiol. 2015, 2, 1-9.

60. Santangeli, P.; Zado, E.S.; Hutchinson, M.D.; Riley, M.P.; Lin, D.; Frankel, D.S.; Marchlinski, F.E. Prevalence and distribution of focal triggers in persistent and long-standing persistent atrial fibrillation. Heart Rhythm. 2016, 13, 374-382. [CrossRef]

61. Rappel, W.J.; Zaman, J.A.; Narayan, S.M. Mechanisms for the termination of atrial fibrillation by localized ablation: Computational and clinical studies. Circ. Arrhythmia Electrophysiol. 2015, 8, 1325-1333. [CrossRef]

62. Hansen, B.J.; Zhao, J.; Csepe, T.A.; Jayne, L.A.; Li, N.; Moore, B.; Weiss, R. Human atrial fibrillation terminated by targeted ablation of localized reentrant drivers guided by dual-sided simultaneous epicardial and endocardial optical mapping. Heart Rhythm. 2014, 11, 2129-2130. [CrossRef]

63. Dang, L.; Virag, N.; Ihara, Z.; Jacquemet, V.; Vesin, J.M.; Schlaepfer, J.; Kappenberger, L. Evaluation of ablation patterns using a biophysical model of atrial fibrillation. Ann. Biomed. Eng. 2005, 33, 465-474. [CrossRef] [PubMed]

64. Zhao, J.; Kharche, S.R.; Hansen, B.J.; Csepe, T.A.; Wang, Y.; Stiles, M.K.; Fedorov, V.V. Optimization of catheter ablation of atrial fibrillation: Insights gained from clinically-derived computer models. Int. J. Mol. Sci. 2015, 16, 10834-10854. [CrossRef] [PubMed]

65. Reumann, M.; Bohnert, J.; Seemann, G.; Osswald, B.; Dossel, O. Preventive ablation strategies in a biophysical model of atrial fibrillation based on realistic anatomical data. IEEE Trans. Biomed. Eng. 2008, 55, 399-406. [CrossRef] [PubMed]

66. Jacquemet, V. Lessons from computer simulations of ablation of atrial fibrillation. J. Physiol. 2016, 594, 2417-2430. [CrossRef]

67. Zahid, S.; Whyte, K.N.; Schwarz, E.L.; Blake III, R.C.; Boyle, P.M.; Chrispin, J.; Calkins, H. Feasibility of using patient-specific models and the "minimum cut" algorithm to predict optimal ablation targets for left atrial flutter. Heart Rhythm. 2016, 13, 1687-1698. [CrossRef]

68. Boyle, P.M.; Zahid, S.; Trayanova, N.A. Using personalized computer models to custom-tailor ablation procedures for atrial fibrillation patients: Are we there yet? Expert Rev. Cardiovasc. Ther. 2017, 15, 339-341. [CrossRef]

69. Bayer, J.D.; Roney, C.H.; Pashaei, A.; Jaïs, P.; Vigmond, E.J. Novel radiofrequency ablation strategies for terminating atrial fibrillation in the left atrium: A simulation study. Front. Physiol. 2016, 7, 108. [CrossRef]

70. Bajorek, B.V.; Krass, I.; Ogle, S.J.; Duguid, M.J.; Shenfield, G.M. Optimizing the Use of Antithrombotic Therapy for Atrial Fibrillation in Older People: A Pharmacist-Led Multidisciplinary Intervention. J. Am. Geriatr. Soc. 2005, 53, 1912-1920. [CrossRef]

71. Kautzner, J.; Neuzil, P.; Lambert, H.; Peichl, P.; Petru, J.; Cihak, R.; Kuck, K.H. EFFICAS II: Optimization of catheter contact force improves outcome of pulmonary vein isolation for paroxysmal atrial fibrillation. EP Eur. 2015, 17, 1229-1235. [CrossRef]

72. Quintanilla, J.G.; Perez-Villacastin, J.; Perez-Castellano, N.; Pandit, S.V.; Berenfeld, O.; Jalife, J.; Filgueiras-Rama, D. Mechanistic approaches to detect, target, and ablate the drivers of atrial fibrillation. Circ. Arrhythmia Electrophysiol. 2016, 9, e002481. [CrossRef]

73. Jadidi, A.S.; Lehrmann, H.; Keyl, C.; Sorrel, J.; Markstein, V.; Minners, J.; Potocnik, C. Ablation of persistent atrial fibrillation targeting low-voltage areas with selective activation characteristics. Circ. Arrhythmia Electrophysiol. 2016, 9, e002962. [CrossRef] [PubMed]

74. Bonso, A.; Fantinel, M.; Scalchi, G.; Ferrara, S.; Indiani, S.; Calore, F.; Licciardello, C. Left atrial model reconstruction in atrial fibrillation ablation: Reliability of new mapping and complex impedance systems. EP Eur. 2016, 19, 1804-1809. [CrossRef] [PubMed]

75. Christensen, K.; Manani, K.A.; Peters, N.S. Simple model for identifying critical regions in atrial fibrillation. Phys. Rev. Lett. 2015, 114, 028104. [CrossRef]

76. Ciaccio, E.J.; Biviano, A.B.; Wan, E.Y.; Peters, N.S.; Garan, H. Development of an automaton model of rotational activity driving atrial fibrillation. Comput. Biol. Med. 2017, 83, 166-181. [CrossRef] [PubMed]

77. Yoshida, K.; Chugh, A.; Good, E.; Crawford, T.; Myles, J.; Veerareddy, S.; Jongnarangsin, K. A critical decrease in dominant frequency and clinical outcome after catheter ablation of persistent atrial fibrillation. Heart Rhythm. 2010, 7, 295-302. [CrossRef] [PubMed]

78. Hassan, S.M.; Javad, H.; Saeed, G.; Redfearn, D.P. Regional Dominant Frequency: A New Tool for Wave Break Identification During Atrial Fibrillation. Front. Cardiovasc. Med. 2018, 5, 79.

79. Lin, Y.J.; Tsao, H.M.; Chang, S.L.; Lo, L.W.; Hu, Y.F.; Chang, C.J.; Wu, T.J. Role of high dominant frequency sites in nonparoxysmal atrial fibrillation patients: Insights from high-density frequency and fractionation mapping. Heart Rhythm. 2010, 7, 1255-1262 [CrossRef]

80. Slocum, J.; Sahakian, A.; Swiryn, S. Diagnosis of atrial fibrillation from surface electrocardiograms based on computer-detected atrial activity. J. Electrocardiol. 1992, 25, 1-8. [CrossRef]

81. Jalife, J. Rotors and spiral waves in atrial fibrillation. J. Cardiovasc. Electrophysiol. 2003, 14, 776-780. [CrossRef]

82. Zhao, J.; Trew, M.L.; Legrice, I.J.; Smaill, B.H.; Pullan, A.J. A Tissue-Specific Model of Reentry in the Right Atrial Appendage. J. Cardiovasc. Electrophysiol. 2009, 20, 675-684. [CrossRef]

83. Guillem, M.S.; Climent, A.M.; Rodrigo, M.; Hernandez-Romero, I.; Liberos, A.; Fernandez-Aviles, F.; Atienza, F. Noninvasive identification of atrial fibrillation drivers: Simulation and patient data evaluation. In Proceedings of the Computing in Cardiology Conference (CinC), Vancouver, BC, Canada, 1-14 September 2016; pp. 121-124.

84. Tobon, C.; Rodriguez, J.F.; Ferrero, J.M., Jr.; Hornero, F.; Saiz, J. Dominant frequency and organization index maps in a realistic three-dimensional computational model of atrial fibrillation. Europace 2012, 14, v25-v32. [CrossRef] [PubMed] 
85. Weber, F.M.; Schilling, C.; Seemann, G.; Luik, A.; Schmitt, C.; Lorenz, C.; Dossel, O. Wave-direction and conduction-velocity analysis from intracardiac electrograms: A single-shot technique. IEEE Trans. Biomed. Eng. 2010, 57, 2394-2401. [CrossRef] [PubMed]

86. Shariat, M.H.; Gazor, S.; Redfearn, D. Cardiac conduction velocity estimation from sequential mapping assuming known Gaussian distribution for activation time estimation error. In Proceedings of the 2016 38th Annual International Conference of the IEEE Engineering in Medicine and Biology Society (EMBC), Orlando, FL, USA, 16-20 August 2016; pp. 505-508.

87. Cantwell, C.D.; Roney, C.H.; Ng, F.S.; Siggers, J.H.; Sherwin, S.J.; Peters, N.S. Techniques for automated local activation time annotation and conduction velocity estimation in cardiac mapping. Comput. Biol. Med. 2015, 65, 229-242. [CrossRef]

88. Markl, M.; Fluckiger, J.; Lee, D.C.; Ng, J.; Goldberger, J.J. Velocity quantification by electrocardiography-gated phase contrast magnetic resonance imaging in patients with cardiac arrhythmia: A simulation study based on real time transesophageal echocardiography data in atrial fibrillation. J. Comput. Assist. Tomogr. 2015, 39, 422-427. [CrossRef] [PubMed]

89. Boyle, P.M.; Hakim, J.B.; Zahid, S.; Franceschi, W.H.; Murphy, M.J.; Vigmond, E.J.; Trayanova, N.A. Comparing Reentrant Drivers Predicted by Image-Based Computational Modeling and Mapped by Electrocardiographic Imaging in Persistent Atrial Fibrillation. Front. Physiol. 2018, 9, 414. [CrossRef]

90. Boyle, P.M.; Hakim, J.B.; Zahid, S.; Franceschi, W.H.; Murphy, M.J.; Prakosa, A.; Chrispin, J. The Fibrotic Substrate in Persistent Atrial Fibrillation Patients: Comparison Between Predictions from Computational Modeling and Measurements from Focal Impulse and Rotor Mapping. Front. Physiol. 2018, 9, 1151. [CrossRef] [PubMed]

91. Parmar, B.R.; Jarrett, T.R.; Burgon, N.S.; Kholmovski, E.G.; Akoum, N.W.; Hu, N.; Ranjan, R. Comparison of left atrial area marked ablated in electroanatomical maps with scar in MRI. J. Cardiovasc. Electrophysiol. 2014, 25, 457-463. [CrossRef]

92. Crozier, A.; Augustin, C.M.; Neic, A.; Prassl, A.J.; Holler, M.; Fastl, T.E.; Niederer, S. A. Image-based personalization of cardiac anatomy for coupled electromechanical modeling. Ann. Biomed. Eng. 2016, 44, 58-70. [CrossRef]

93. Larburu, N.; Lopetegi, T.; Romero, I. Comparative study of algorithms for atrial fibrillation detection. In Proceedings of the Computing in Cardiology, Hangzhou, China, 18-21 September 2011; pp. 265-268.

94. McGillivray, M.F.; Cheng, W.; Peters, N.S.; Christensen, K. Machine learning methods for locating re-entrant drivers from electrograms in a model of atrial fibrillation. R. Soc. Open Sci. 2018, 5, 172434. [CrossRef]

95. Chorro, F.J.; Mainar, L.; Sanchis, J.; Canoves, J.; Porres, J.C.; Guerrero, J.; Millet, J.; Llavador, E.; Such, L.M.; Egea, S.; et al. The activation patterns during atrial fibrillation in an experimental model. Rev. Esp. Cardiol. 1999, 52, 327-338. [CrossRef]

96. Ugarte, J.P.; Orozco-Duque, A.; Tobon, C.; Kremen, V.; Novak, D.; Saiz, J.; Oesterlein, T.; Schmitt, C.; Luik, A.; Bustamante, J. Dynamic approximate entropy electroanatomic maps detect rotors in a simulated atrial fibrillation model. PLoS ONE 2014, 9, e114577. [CrossRef] [PubMed]

97. Lahdenoja, O.; Hurnanen, T.; Iftikhar, Z.; Nieminen, S.; Knuutila, T.; Saraste, A.; Koivisto, T. Atrial fibrillation detection via accelerometer and gyroscope of a smartphone. IEEE J. Biomed. Health Inform. 2018, 22, 108-118. [CrossRef] [PubMed]

98. Brasier, N.; Raichle, C.J.; Dörr, M.; Becke, A.; Nohturfft, V.; Weber, S.; Eckstein, J. Detection of atrial fibrillation with a smartphone camera: First prospective, international, two-centre, clinical validation study (DETECT AF PRO). Ep Eur. 2019, $21,41-47$. [CrossRef] [PubMed]

99. Chang, E.T.; Lin, Y.T.; Galla, T.; Clayton, R.H.; Eatock, J. A Stochastic Individual-Based Model of the Progression of Atrial Fibrillation in Individuals and Populations. PLoS ONE 2016, 11, e0152349. [CrossRef] [PubMed]

100. Tsao, H.M.; Yu, W.C.; Cheng, H.C.; Wu, M.H.; Tai, C.T.; Lin, W.S.; Chen, S.A. Pulmonary vein dilation in patients with atrial fibrillation: Detection by magnetic resonance imaging. J. Cardiovasc. Electrophysiol. 2001, 12, 809-813. [CrossRef]

101. McGann, C.J.; Kholmovski, E.G.; Oakes, R.S.; Blauer, J.J.; Daccarett, M.; Segerson, N.; DiBella, E.V. New magnetic resonance imaging-based method for defining the extent of left atrial wall injury after the ablation of atrial fibrillation. J. Am. Coll. Cardiol. 2008, 52, 1263-1271. [CrossRef]

102. Daccarett, M.; Badger, T.J.; Akoum, N.; Burgon, N.S.; Mahnkopf, C.; Vergara, G.; MacLeod, R.S. Association of left atrial fibrosis detected by delayed-enhancement magnetic resonance imaging and the risk of stroke in patients with atrial fibrillation. J. Am. Coll. Cardiol. 2011, 57, 831-838. [CrossRef]

103. Sohns, C.; Lemes, C.; Metzner, A.; Fink, T.; Chmelevsky, M.; Maurer, T.; Mathew, S. First-in-man analysis of the relationship between electrical rotors from noninvasive panoramic mapping and atrial fibrosis from magnetic resonance imaging in patients with persistent atrial fibrillation. Circ. Arrhythmia Electrophysiol. 2017, 10, e004419. [CrossRef]

104. Marrouche, N.F.; Wilber, D.; Hindricks, G.; Jais, P.; Akoum, N.; Marchlinski, F.; Deneke, T. Association of atrial tissue fibrosis identified by delayed enhancement MRI and atrial fibrillation catheter ablation: The DECAAF study. JAMA 2014, 311, 498-506. [CrossRef]

105. Cochet, H.; Dubois, R.; Yamashita, S.; Al Jefairi, N.; Berte, B.; Sellal, J.M.; Denis, A. Relationship between fibrosis detected on late gadolinium-enhanced cardiac magnetic resonance and re-entrant activity assessed with electrocardiographic imaging in human persistent atrial fibrillation. JACC Clin. Electrophysiol. 2018, 4, 17-29. [CrossRef]

106. Fonseca, A.C.; Alves, P.; Inacio, N.; Marto, J.P.; Viana-Baptista, M.; Pinho-e-Melo, T.; Almeida, A.G. Patients With Undetermined Stroke Have Increased Atrial Fibrosis: A Cardiac Magnetic Resonance Imaging Study. Stroke 2018, 49, 734-737. [CrossRef] [PubMed]

107. Gal, P.; Marrouche, N.F. Magnetic resonance imaging of atrial fibrosis: Redefining atrial fibrillation to a syndrome. Eur. Heart J. 2015, 38, 14-19. [CrossRef] [PubMed] 
108. Cochet, H.; Mouries, A.; Nivet, H.; Sacher, F.; Derval, N.; Denis, A.; Laurent, F. Age, atrial fibrillation, and structural heart disease are the main determinants of left atrial fibrosis detected by delayed-enhanced magnetic resonance imaging in a general cardiology population. J. Cardiovasc. Electrophysiol. 2015, 26, 484-492. [CrossRef] [PubMed]

109. Geremia, E.; Clatz, O.; Menze, B.H.; Konukoglu, E.; Criminisi, A.; Ayache, N. Spatial decision forests for MS lesion segmentation in multi-channel magnetic resonance images. NeuroImage 2011, 57, 378-390. [CrossRef]

110. Kandwal, R.; Kumar, A.; Bhargava, S. Existing Image Segmentation Techniques. Int. J. Adv. Res. Comput. Sci. Softw. Eng. 2014, $4,166-170$

111. Zaitoun, N.M.; Aqel, M.J. Survey on image segmentation techniques. Procedia Comput. Sci. 2015, 65, 797-806. [CrossRef]

112. Sharma, P.; Suji, J. A review on image segmentation with its clustering techniques. Int. J. Signal Process. Image Process. Pattern Recognit. 2016, 9, 209-218. [CrossRef]

113. Erdt, M.; Steger, S.; Sakas, G. Regmentation: A new view of image segmentation and registration. J. Radiat. Oncol. Inform. 2017, $4,1-23$.

114. Camara, O.; Mansi, T.; Pop, M.; Rhode, K.; Sermesant, M.; Young, A. Statistical Atlases and Computational Models of the Heart-Imaging and Modeling Challenges. Stat. Atlases Comput. Model. Heart 2014, 8896, 296.

115. Fastl, T.E.; Tobon-Gomez, C.; Crozier, A.; Whitaker, J.; Rajani, R.; McCarthy, K.P.; Bishop, M.J. Personalized computational modeling of left atrial geometry and transmural myofiber architecture. Med. Image Anal. 2018, 47, 180-190. [CrossRef]

116. Fastl, T.E.; Tobon-Gomez, C.; Crozier, W.A.; Whitaker, J.; Rajani, R.; McCarthy, K.P.; Bishop, M.J. Personalized modeling pipeline for left atrial electromechanics. In Proceedings of the Computing in Cardiology Conference (CinC), Vancouver, BC, Canada, 11-14 September 2016; pp. 225-228.

117. Taneja, A.; Ranjan, P.; Ujjlayan, A. A performance study of image segmentation techniques. In Proceedings of the 20154 th International Conference on Reliability, Infocom Technologies and Optimization (ICRITO) (Trends and Future Directions), Noida, India, 2-4 September 2015; pp.1-6.

118. Sohns, C.; Metzner, A.; Chmelevsky, M.; Kuck, K.H. A new algorithm to visualize the individual relationship between electrical rotors from non-invasive panoramic mapping and atrial fibrosis to guide ablation of persistent atrial fibrillation. Clin. Res. Cardiol. 2018, 107, 444-446. [CrossRef] [PubMed]

119. Maryam, H.; Mustapha, A.; Younes, J. A multilevel thresholding method for image segmentation based on multiobjective particle swarm optimization. In Proceedings of the 2017 International Conference on Wireless Technologies, Embedded and Intelligent Systems (WITS), Fez, Morocco, 19-20 April 2017; pp. 1-6.

120. Duraisamy, S.P.; Kayalvizhi, R. A new multilevel thresholding method using swarm intelligence algorithm for image segmentation. J. Intell. Learn. Syst. Appl. 2010, 2, 126. [CrossRef]

121. Datta, N.S.; Dutta, H.S.; Majumder, K.; Chatterjee, S.; Wasim, N.A. A Survey on the Application of Multi-Objective Optimization Methods in Image Segmentation. In Multi-Objective Optimization; Springer: Singapore, 2018; pp. 269-278.

122. Chen, L.C.; Papandreou, G.; Kokkinos, I.; Murphy, K.; Yuille, A.L. Deeplab: Semantic image segmentation with deep convolutional nets, atrous convolution, and fully connected crfs. IEEE Trans. Pattern Anal. Mach. Intell. 2018, 40, 834-848. [CrossRef]

123. Rahkar Farshi, T.; Demirci, R.; Feizi-Derakhshi, M.R. Image Clustering with Optimization Algorithms and Color Space. Entropy 2018, 20, 296. [CrossRef] [PubMed]

124. Nakib, A.; Oulhadj, H.; Siarry, P. Non-supervised image segmentation based on multiobjective optimization. Pattern Recognit. Lett. 2008, 29, 161-172. [CrossRef]

125. Piccini, J.P.; Fauchier, L. Rhythm control in atrial fibrillation. Lancet 2016, 388, 829-840. [CrossRef]

126. Friberg, J.; Buch, P.; Scharling, H.; Gadsbøll, N.; Jensen, G.B. Rising rates of hospital admissions for atrial fibrillation. Epidemiology 2003, 14, 666-672. [CrossRef]

127. Deshmukh, A.; Patel, N.J.; Pant, S.; Shah, N.; Chothani, A.; Mehta, K.; Grover, P.; Singh, V.; Vallurupalli, S.; Savani, G.T.; et al. In-Hospital Complications Associated With Catheter Ablation of Atrial Fibrillation in the United States Between 2000 and 2010. Circulation 2013, 128, 2104-2112. [CrossRef]

128. Tayal, A.H.; Tian, M.; Kelly, K.M.; Jones, S.C.; Wright, D.G.; Singh, D.; Gupta, R. Atrial fibrillation detected by mobile cardiac outpatient telemetry in cryptogenic TIA or stroke. Neurology 2008, 71, 1696-1701. [CrossRef]

129. Ng, J.; Gordon, D.; Passman, R.S.; Knight, B.P.; Arora, R.; Goldberger, J.J. Electrogram morphology recurrence patterns during atrial fibrillation. Heart Rhythm. 2014, 11, 2027-2034. [CrossRef]

130. Verma, A.; Jiang, C.Y.; Betts, T.R.; Chen, J.; Deisenhofer, I.; Mantovan, R.; Albenque, J.P. Approaches to catheter ablation for persistent atrial fibrillation. N. Engl. J. Med. 2015, 372, 1812-1822. [CrossRef] [PubMed]

131. Abhishek, F.; Zhang, Z.; Qin, Z.; Dudley, S.C.; Wang, Y.; Dabhadkar, K.; Heist, E. Impact of treatment crossovers on clinical outcomes in the rate and rhythm control strategies for atrial fibrillation: Insights from the affirm (atrial fibrillation follow-up investigation of rhythm management) trial. J. Am. Coll. Cardiol. 2017, 69, 476. [CrossRef]

132. Rajeswaran, J.; Blackstone, E.H.; Ehrlinger, J.; Li, L.; Ishwaran, H.; Parides, M.K. Probability of atrial fibrillation after ablation: Using a parametric nonlinear temporal decomposition mixed effects model. Stat. Methods Med. Res. 2018, 27, 126-141. [CrossRef] [PubMed]

133. Ionescu-Ittu, R.; Abrahamowicz, M.; Jackevicius, C.A.; Essebag, V.; Eisenberg, M.J.; Wynant, W.; Pilote, L. Comparative effectiveness of rhythm control vs rate control drug treatment effect on mortality in patients with atrial fibrillation. Arch. Intern. Med. 2012, 172, 997-1004. [CrossRef] [PubMed] 
134. Calvo, D.; Filgueiras-Rama, D.; Jalife, J. Mechanisms and Drug Development in Atrial Fibrillation. Pharmacol. Rev. 2018, 70, 505-525. [CrossRef]

135. Gillinov, A.M.; Bagiella, E.; Moskowitz, A.J.; Raiten, J.M.; Groh, M.A.; Bowdish, M.E.; Smith, R.L. Rate control versus rhythm control for atrial fibrillation after cardiac surgery. N. Engl. J. Med. 2016, 374, 1911-1921. [CrossRef]

136. Lafuente-Lafuente, C.; Valembois, L.; Bergmann, J.F.; Belmin, J. Antiarrhythmics for maintaining sinus rhythm after cardioversion of atrial fibrillation. Cochrane Database Syst. Rev. 2015. . [CrossRef]

137. Abraham, J.M.; Saliba, W.I.; Vekstein, C.; Lawrence, D.; Bhargava, M.; Bassiouny, M.; Poe, S. Safety of oral dofetilide for rhythm control of atrial fibrillation and atrial flutter. Circ. Arrhythmia Electrophysiol. 2015, 8, 772-776. [CrossRef]

138. Di Biase, L.; Mohanty, P.; Mohanty, S.; Santangeli, P.; Trivedi, C.; Lakkireddy, D.; Casella, M. Ablation vs. amiodarone for treatment of persistent atrial fibrillation in patients with congestive heart failure and an implanted device: Results from the AATAC multicenter randomized trial. Circulation 2016, 133, 1637-1644. [CrossRef]

139. Frommeyer, G.; Schmidt, M.; Clauss, C.; Kaese, S.; Stypmann, J.; Pott, C.; Milberg, P. Further insights into the underlying electrophysiological mechanisms for reduction of atrial fibrillation by ranolazine in an experimental model of chronic heart failure. Eur. J. Heart Fail. 2012, 14, 1322-1331. [CrossRef]

140. Milberg, P.; Frommeyer, G.; Ghezelbash, S.; Rajamani, S.; Osada, N.; Razvan, R.; Belardinelli, L.; Breithardt, G.; Eckardt, L. Sodium channel block by ranolazine in an experimental model of stretch-related atrial fibrillation: Prolongation of interatrial conduction time and increase in post-repolarization refractoriness. Europace 2013, 15, 761-769. [CrossRef] [PubMed]

141. Lugenbiel, P.; Wenz, F.; Syren, P.; Geschwill, P.; Govorov, K.; Seyler, C.; Bruehl, C. TREK-1 (K2p 2.1) $\mathrm{K}^{+}$channels are suppressed in patients with atrial fibrillation and heart failure and provide therapeutic targets for rhythm control. Basic Res. Cardiol. 2017, 112, 8. [CrossRef] [PubMed]

142. Inada, S.; Shibata, M.D.; Ashihara, M.D.; Ikeda, M.D.; Mark, R. Simulation of ventricular rate control during atrial fibrillation using ionic channel blockers. J. Arrhythmia 2017, 33, 302-309. [CrossRef] [PubMed]

143. Krueger, M.W.; Rhode, K.S.; O'Neill, M.D.; Rinaldi, C.A.; Gill, J.; Razavi, R.; Doessel, O. Patient-specific modeling of atrial fibrosis increases the accuracy of sinus rhythm simulations and may explain maintenance of atrial fibrillation. J. Electrocardiol. 2014, 47, 324-328. [CrossRef]

144. Shah, R.; Al-Darzi, W.; Greenbaum, A.; Eng, M.; Wang, D.D.; Greenberg, J.; Singh, G. Safety of rhythm control and cardioversion for patients with recurrent symptomatic atrial fibrillation in the absence of anticoagulation following percutaneous left atrial appendage occlusion. J. Am. Coll. Cardiol. 2018, 71, A293. [CrossRef]

145. Ouyang, Z.L.; Sun, L.P.; Chi, H.; Xia, L.; Gong, Y.L.; Fan, Y.B. Potential Maintenance Mechanism in Atrial Fibrillation Patients Subject to Different Treatment Procedures: A Preliminary Study Based on a Human Atrial Model. Curr. Med. Sci. 2018, 38, 422-426. [CrossRef]

146. Hamada, R.; Muto, S. Simple risk model and score for predicting of incident atrial fibrillation in Japanese. J. Cardiol. 2019, 73, 65-72. [CrossRef]

147. Sears, S.F.; Anthony, S.; Harrell, R.; Tripp, C.; Bowman, J.; Khan, S.; Naniwadekar, A. Managing atrial fibrillation: The intersection of cardiology, health psychology, and the patient experience. Health Psychol. 2021. [CrossRef] 